\title{
STUDIES ON READING THE URBAN CENTRE VIA COGNITIVE MAPS: THE EXAMPLE OF ESKIŞEHIR, TURKEY
}

\author{
AYSEN CELEN OZTURK \\ Department of Architecture, Eskişehir Osmangazi University, Turkey
}

\begin{abstract}
Cities are open spaces where people exist together, socialize and perform the actions of encountering and meeting others. Urbanites carry out their socio-cultural life through their activities in exterior space within the construct of the urban physical environment. Social structuring emerges in open public spaces, in which the relationship between the individual and society is reinforced by the physical environment. Nevertheless, today, the rapid growth of the uncontrolled urban development in a complex pattern increasingly renders it difficult for the urbanite to detect and easily scrutinize exterior spaces in the city. The environmental image acquired by the individual gives them the feeling of being emotionally secure when bearing this image in mind. The elevated qualities of legibility and wayfinding in the cities are of the most important "urban design principles". Urban legibility means that an environment is discernable and is perceivable within continuity. The more rapid a city can create an image in mind, the more legible it becomes. In this study, the city of Eskişehir, which is located in the northwestern part of Turkey and has a history that dates back to Phrygian civilization, is scrutinized. Apart from being an industrial and commercial city, Eskişehir has been a university city since the $1950 \mathrm{~s}$. Currently, university students comprise $10 \%$ of the urban population. In this study, reading the city was carried out via the cognitive map of the university students who experience the city for a while.
\end{abstract}

Keywords: Eskişehir, cognitive map, legibility, image of the city, sustainable planning.

\section{INTRODUCTION}

Cities, where the needs of the society such as housing, occupation, education, recreation and entertainment are fulfilled, are settlements that are in constant social development. The ways of perceiving and reading the cities might be subject to change, due to the dynamic nature of the cities. Perception is an active process that involves receiving or acquiring information from the environment. This process is where cognition and reality meet. Humans perceive the details around them by moving their eyes, head and their body. Due to the increase in experience, the amount of detail and relationships that could be perceived increases [1]. In other words, humans conceptualize the received information through their senses via interpreting that information in their minds. Hence, it becomes necessary to acknowledge and comprehend the environment we live in, in order to be able to benefit from it, adapt to it, and to adapt the environment to ourselves [2].

The "experiences" an individual has in the two-way interaction between the individual and the environment enable the individual to perceive and create an environmental image. Downs and Stea, who work on environmental psychology, describe perception as the encoding, keeping, recalling and decoding of information, which is gathered from the spatial environment [3].

The emblematic images, which are acquired through the past experience of the individual, are preserved in long-term memory and in new encounters the environment is perceived through association, matching and comparison. The individual chooses the components of the environment according to his own prospects and objectives, organizes them in his mind, assigns meanings to them and creates an image which belongs to that 
environment. This process progresses and differentiates depending on the mutual interaction and adaptability of the individual. Therefore, different groups might have rather diverse images of the same reality [4].

According to the filter model developed by Rapoport, differences between the perceived form and actual form of the environment are formed through the cultural and individual factors acting as a filter upon the actual environment [5].

Various researchers, who conducted studies on urban tissue, were inspired by the diverse perceptions of a structured physical environment for different people. Of these studies, the conceptual typology of Lynch is highly acknowledged; Lynch conducts studies on urban perception. In his studies, Lynch arrived at the conclusion that the perception of urban tissue was shaped via the imaginations created by the urban image in the individual's mind [6]. The urban image could be defined as a generalized cognitive picture of the external environment. It is possible to comprehend the formation of the urban image in three phases; namely, the input - environmental information, the process - processing the environmental data in the individual's mind, and the output - the process of formation of the environmental image the mind carries [7].

Environmental characteristics that affect the individual psychologically are defined as legibility, consisting of a meaning, creating an association, originality, harmony with the built environment, harmony of the environmental elements with each other, and the diversity of environmental elements [8]. The relationship between the form, color and the environment should be readable for a vivid and powerful emergence of the urban image in the mind. Objects do not only influence through their visibility, but also through senses. Legibility could be defined as the discernibility of an environment and capability to organize this environment in a consistent pattern [9]. According to Lynch, the easier an environment creates an image in mind, the more readable it becomes [6]. Legibility, according to Herzog and Leverich, refers to the features of an environment that could provide a meaning that helps to create a cognitive map [10]. O'Neill claims that legibility refers to the degree to which the built environment could be of assistance in constructing an effective cognitive image or cognitive map [11]. The principal concepts in defining spatial legibility are simplicity, consistency, comprehensibility, perceptibility, and capability to be organized. All abovementioned concepts indicate the features that stem from the organization of the space. However, it is not possible to measure legibility through these concepts. Köseoğlu (2011) defined two variables in establishing the definition of legibility. One of these variables is the degree of complexity of spatial construct, which is utilized to convey the two-dimensional knowledge of the space [12]. The other variable is the discernibility of the symbolic elements/landmarks that enables us to develop the knowledge of three-dimensionality. Furthermore, the abovementioned two variables are the primary elements of the spatial information used during wayfinding [12]. In this study, the students, who are trained in the school of architecture, were requested to describe the city center of Eskişehir, the city that they started living in a few years ago, by using three-dimensional images over two-dimensional draft plans in order to create a cognitive map. For the analysis of the generated cognitive maps, Kevin Lynch's elements, paths, edges, districts, nodes/focal points, and landmarks are used.

\section{THE PLACE OF ESKIŞEHIR IN TURKEY AND ITS HISTORICAL DEVELOPMENT}

In this study, the city of Eskişehir, which has a history that dates back to Phrygian civilization, is scrutinized. Eskişehir, which was founded in the northwest of the Central Anatolian region of Turkey, located on the western edge of the Asian Continent, is 
strategically placed between Ankara, the capital of Turkey, and Istanbul, as one of the important centers of world trade. While Eskişehir has developed as a major trade city on the Hamburg-Baghdad railway route in the historical process, it has also been selected as one of the exemplary industrial cities of the republican Turkey.

Eskişehir, an important threshold on the Anatolian connection of the Hamburg-Bagdad railroad, gained importance on this trade axis during the end of 1800s. The railways, which were constructed entirely depending on the foreign capital as an outcome of the westernization efforts of the Ottoman Empire before the proclamation of the republic, became one of the most important institutions of the Republican Era after the nationalization in 1929. The existence of railroad transportation in Eskişehir, as a required feature for the development of industry in the city, is among the fundamental reasons for her designation as one of the prioritized industrial cities of republican Turkey. Immigrants from Balkans and Caucasus stood for an important positive element in the history and industrial development of Eskişehir [13]. The presence of the railways in Turkey, as part of the newly established state in 1923, became one of the most effective supporters of republican modernism. During this period, according to the state policies on transportation, the priority was given to railroads.

Eskişehir, which had a population of below 30,000 until the Republican Era, was composed of two districts in 1923 as residential areas. One of these districts is the Odunpazari, an old residential district on the mountain foot in the south, and the other is the area around Porsuk in the north where the trade activities took place and where migrants partially inhabited. In Gaye Ertin's book 'The Evolution of Habitation in Eskissehir' it is noted that with the effect of industrialization after the establishment of the republic, the city population experienced rapid growth [14, p. 23]:

Between 1923-50, the population of the province displays a supportive feature on the spread and development of residential areas'. Hence, between 1927-50, the population increased twice as much as the number of the earlier period. Beside the natural increase in the population, the new comers from other places (Sivrihisar, Kutahya, Sogut) realized this growth. In this growth, as well as the role of three major state institutions, namely The Sugar Factory, The Railway Repair Factory, The Plane Maintenance Hangars and Workshop; the large and small factories established by the private sector were also important.

During the period when there was no construction plan for the city, the spatial borders and enlargement were directed by the residential areas as extensions of the industry; starting in 1956, spatial enlargement was realized in a planned way. In 1956, the first master plan for the city was prepared and new residential areas began to appear. The physical construction of the city of Eskişehir was planned in three stages, to take place in the years of 1956, 1986 and 2002, respectively [15].

Today, the city center of Eskişehir remains in between an area of $\sim 23 \mathrm{~km}$ in the direction of east and west and from $\sim 10 \mathrm{~km}$ in the direction of north and south. With the inclusion of Eskişehir in the category of metropolis among the local governments in 1993, two other municipalities were established in addition to the metropolitan municipality. The municipalities of Tepebasi and Odunpazari were named according to the areas they belong to. According to the data presented in the workshop, the province comprises an area of $1600 \mathrm{~km}^{2}$ in sum and its approximate population is 631,905 people. The province is composed of 94 neighborhoods and 51 villages connected to the city's administration. 
Although quite far away from the typical boundaries of continental Europe, national media and the municipality have increasingly branded Eskişehir as a European city. Now in his fourth consecutive term, Mayor Yılmaz Büyükerşen exerts a type of "Republican populism" typical of 1930s Turkey, which he combines with a European type of social democracy that favors the use of public spaces by people from diverse social, family, and cultural backgrounds [16]. On the other hand, two of the biggest public universities in Turkey, Anadolu University and Eskişehir Osmangazi University, established in 1958 and 1970 respectively, redoubled the importance of the city as being an education center. Although in the past the image of Eskişehir was the "hot water - hot springs town" and the "industrial city", nowadays the image has shifted towards being a "university and tourism city" [17].

The alterations and transformations conducted in the transportation plans of the city after the year 2000 contributed to the sustainable urban development of Eskişehir through enhancing the city's legibility. According to the 2015 report of the workshop of Sustainable Urban Mobility Plans (SUMP), Eskişehir became the first city in Turkey to revise the "Transportation Master Plans" in accordance with SUMP data. The report states that public transportation vehicles in Eskişehir, which utilize clean energy, are constantly being increased and the efforts to expand the pedestrian zones continue [18]; Eskişehir city center is appropriate for pedestrian access (being a city of lowlands and a vastness of pedestrianized roads), and the facility of a light rail system in the city center has increased pedestrian access and tram utilization for in-city transportation. According to the Urban Mobility Observatory data, Eskişehir city center is described as a pedestrian-friendly city [19].

This study comprises a pilot scheme of a scientific research project titled "A Model Suggestion for Increasing the Legibility of the Walkable City Center of Eskişehir and Pedestrian-Focused Wayfinding Qualification" (ESKMOKA) ongoing at Eskişehir Osmangazi University. This project is designated to enhance the legibility and wayfinding characteristic of the city for a pedestrian, both for the locals and for the short-term users such as tourists and students, who have rapidly been increasing in numbers for the last years. Through the implementation of the project, which is jointly prepared with the local administration, it is contemplated that individuals would develop a more secure relationship with the urban environment and would contribute to the development of a sustainable urban environment.

In order to enhance the organized and uninterrupted legibility and wayfinding characteristics of the city center of Eskişehir through nodes, a three-step work plan was developed. In this study, the aim is to "determine the characteristics of wayfinding and how the short-term user in the city reads the current situation of the city", "prepare the legibility and wayfinding action plan", and "create an urban design language, which is specific to Eskişehir, in terms of legibility and wayfinding".

\section{COGNITIVE MAPPING}

Cognitive maps are the conceptual manifestations of place-based experience and reasoning that allows one to determine where one is at any moment and what place-related objects occur in that vicinity or in the surrounding space. Cognitive mapping is the process of encoding, storing, and manipulating experienced and sensed information that can be spatially referenced. What guides this cognitive processing is being actively researched in cognitive psychology, neuropsychology, and related fields. But, essentially, cognitive mapping involves sensing, encoding, and storing experienced information in the mind. This is referred to as "declarative" knowledge [20]. 
Cognitive mapping is the method of transposing the natural process that occurs in the mind through the combination of keywords and images to paper. In addition, it is a graphical narrative, in which the keywords are reinforced by colors, pictures and symbols, and this graphical narrative is created through the image that emerges via the connection established with memories, recollections, and concepts. Since cognitive maps are unique designs that belong to an individual, each individual communicates the information he/she constructs in their mind onto the paper [21]. Walking in the city center enables us to establish a connection with the environment we are in and provides us the chance to develop personal experiences. Additionally, Walking is the most significant and common mode of transportation in daily life. The vast majority of university students in Eskişehir experience the city center via walking or using public transport such as trams and buses. Consequently, as the sample of this study, students who mainly experience the city through walking were selected.

Numerous systems have been developed to display large collections of data for urban contexts; however, most have focused on the layering of single dimensions of data and manual calculations to understand relationships within the urban environment. Furthermore, these systems often limit the user's perspectives on the data, thereby diminishing the user's spatial understanding of the viewing region. In this paper, we explore cognitively mapped intuitive understandings of the urban data. The objective of this study is to analyze what the cognitive elements that constitute Eskişehir city center currently are and how the city is read, through the mind maps of the university students who recently arrived in the city.

\section{MATERIALS AND METHODS}

Qualitative research methods, which are considered more significant in comprehending phenomena and events rather than generalizing them, are used in the studies focusing on social structure, since humans and society exhibit a variable structure. Qualitative research is defined as the monitoring of a process, which aims to reveal the psychological state, perceptions and phenomena related to an individual in a natural setting, in a realistic and holistic manner, by using qualitative data collection techniques such as observation, interview and document analysis. Qualitative research is a method which is based on a holistic viewpoint within disciplines, and adopts an interpretive approach in scrutinizing a research problem [22]. Descriptive analysis is a qualitative research method in which the conceptual framework is pre-defined and sub-objectives are created, and the data are interpreted.

This study adopts the "Qualitative Research/Descriptive Analysis Method" as its conceptual framework for reading the urban context via utilizing the basic elements (paths, edges, districts, nodes and landmarks) defined by Lynch. The obtained data are interpreted according to the predetermined conceptual framework [23].

\subsection{Sample}

In Eskişehir, university students experience the city in the short-term (about 4-5 years) and particularly prefer to walk short distances while using trams and buses for other in-city transportation requirements. In the first phase of the scientific research project, a pilot study group composed of university students, as short-term users who experienced the city, was established. In establishing the pilot study group, it was considered to select students who could communicate easily, created experiences through undergoing the city life for a short period, and who had the time to transfer these experiences. Therefore, students who attend 
Eskişehir Osmangazi University's Department of Architecture were selected and the study was conducted with a student group of approximately 50 people.

\subsection{Data collection}

The students, who constitute the sample of this study, were requested to describe the urban environment in which they continue their daily lives in Eskişehir, through cognitive maps. It was suggested that all observers could use A3-sized paper, orientated horizontally, in creating their cognitive maps. The variation in using drafting equipment was left to the observers. The problem was presented as in the below, in order to encourage the observer to create his/her cognitive map.

\subsection{Definition of the problem}

Participating students were asked to narrate the areas of Eskişehir city center that they use in their everyday lives in a holistic manner.

\subsection{Form of representation}

Participating students were asked to prepare a map/sketch using geometrical shapes, silhouettes, graphical representation, symbols and written language.

\subsection{Urban representation}

Urban representations could be constructed using structural and perceptual elements that define the urban space, such as landmarks, images (water, statues, buildings, roads, etc.).

Different forms of expressions selected from the cognitive maps created by the students are presented in Fig. 1. Commonly, structure and nodes are demonstrated through twodimensional plan projection and three-dimensional perspective projections in the creation of the cognitive maps. In addition, activities that narrate the relationship established with the city and the psychological perception of the physical environment in which the individual lives in are observed in the spatial construct created by the individuals who draw the cognitive maps. Through scrutinizing the current student's cognitive maps, it is possible to generate information about the areas that university students commonly utilize and about their forms of socialization.

Through the examination of the cognitive maps that constitute the basis of the study and are drawn by 50 students, Lynch's five fundamental elements (paths, edges, districts, nodes, and landmarks) that designate the legibility of a city and the other elements of the relationship established with the city were evaluated. The results of the analysis of the cognitive maps are given in Table 1.
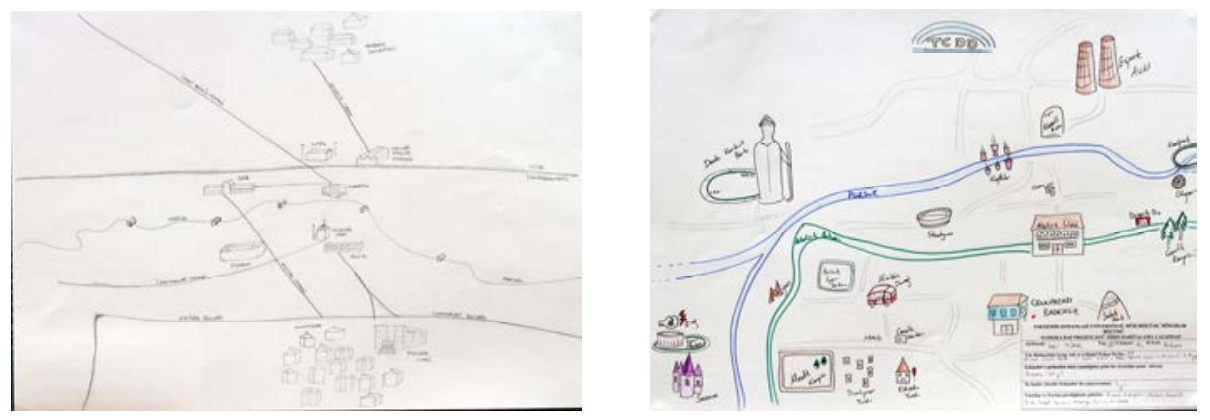

Figure 1: Examples for the cognitive maps of students. 
Table 1: Analysis of the cognitive maps.

\begin{tabular}{|c|c|}
\hline $\begin{array}{l}\text { Natural and artificial EDGES } \\
\text { that shape the city }\end{array}$ & $\begin{array}{ll}\text { - } & \text { Porsuk River } \\
\text { - } & \text { Railroad line } \\
\text { - } & \text { Ring roads } \\
\text { Topography of Odunpazar } 1\end{array}$ \\
\hline DISTRICTS & $\begin{array}{ll}\text { - } & \text { Old Bazaar (Taşbaşı, Hamamyolu Bazaar) } \\
\text { - } & \text { Waterfront area (Adalar and Köprübaş1) } \\
& \text { Turkish Post (Vilayet Square, Eskişehir Metropolitan Municipality, PTT - } \\
\text { - } & \text { New bazaar (Köprübaş1, Fabrikalar and Yeni Bağlar areas) } \\
\text { - } & \text { Historical district/Odunpazarı }\end{array}$ \\
\hline Eskişehir's LANDMARKS & $\begin{array}{ll}\text { - } & \text { TCDD (Turkish State Railways) Train Station } \\
\text { - } & \text { Station building } \\
\text { - } & \text { Stadium } \\
\text { - } & \text { Espäürk High School } \\
\text { - } & \text { Kanatlı shopping mall } \\
\text { - } & \text { Neo/Carrefour shopping mall } \\
\text { - } & \text { Özdilek shopping mall } \\
\text { - } & \text { Esnaf Sarayı shopping mall } \\
\text { - } & \text { Eskernorate building } \\
\text { - } & \text { Industrial chimneys and renewed factory buildings } \\
\text { - } & \text { Air Force Hospital } \\
\text { - } & \text { Reşadiye Mosque } \\
- & \text { Wax Museum } \\
\text { - } & \text { Hotel Rixos } \\
- & \text { Bridges } \\
- & \text { Military Officer's Club } \\
- & \text { Archeology Museum } \\
\text { - } & \text { Atatürk Boulevard, Migros shopping center } \\
\end{array}$ \\
\hline $\begin{array}{l}\text { NODES } \\
\text { Statues }\end{array}$ & $\begin{array}{ll}\text { - } & \text { Sazova Park } \\
\text { - } & \text { Dede Korkut Park } \\
\text { - } & \text { Kelale Park } \\
\text { - } & \text { Dede Kork } \\
\text { - } & \text { Flower Bundles } \\
\text { - } & \text { Cengiz Topel Statue } \\
\text { - } & \text { Statue of the fishing man } \\
\text { - } & \text { Statue of those who chat on a bench }\end{array}$ \\
\hline $\begin{array}{l}\text { PATHS } \\
\text { Roads and boulevards }\end{array}$ & $\begin{array}{ll}\text { - } & \text { Istanbul-Ankara Ring Road } \\
\text { - } & \text { Kütahya-Afyon Ring Road } \\
\text { - } & \text { Atatürk Boulevard } \\
\text { - } & \text { Şair Fizuli Road } \\
\text { - } & \text { Adatürk Road } \\
\text { - } & \text { İki Eylül Road } \\
\text { - } & \text { Yunus Emre Road }\end{array}$ \\
\hline Activities used & $\begin{array}{l}\text { Shopping, café-restaurant, stationery, sports, recreation, culture and arts, } \\
\text { education, and entertainment }\end{array}$ \\
\hline Transportation & $\begin{array}{ll}- & \text { Tram } \\
\text { - } & \text { Bus } \\
\text { - } & \text { Midi-bus } \\
\text { - } & \text { Bicycle } \\
\end{array}$ \\
\hline
\end{tabular}


Some of the cognitive maps, which were created as freehand drawings, were converted into graphical representation in the analysis phase. According to Fig. 2, it is possible to assert that converting the freehand drawings into a language of graphical representation increases the readability of the cognitive maps.

\subsection{Findings}

This study was conducted as a phase of the scientific project, "A Model Suggestion for Increasing the Legibility of the Walkable City Center of Eskişehir and Pedestrian-Focused Wayfinding Qualification". It comprises the analysis of cognitive maps created by university students who have been experiencing the city for a short period of time. As a result of this study, primarily, the urban elements constituting the legibility of Eskişehir city center were determined through the cognitive maps of the university students, who had newly arrived in the city and had been experiencing it for a short period. As the cognitive maps were examined, it was noticed that the two-dimensional complexity of the city and the three-dimensional landmarks were depicted, as mentioned in the study of Köseoğlu and Onder in 2011 [12], in transferring the spatial information encompassed in the memory of the individuals. Furthermore, the spatial relation established by the individual with the city becomes an important input for legibility. Particularly, it is observed that residential areas in the city (residential areas, schools, restaurant and cafes, culture and sports centers, etc.) and activities (accommodation, eating and drinking, education, sports, culture and entertainment etc.) affected the legibility and rendered legibility subjective in the cognitive maps of university students. The cognitive maps that were analyzed demonstrated that the city center of Eskişehir, which emerged in a historical process, is not complicated in terms of legibility and wayfinding. The main elements determining in the city are the Porsuk River that runs through it, the northern ring road (Istanbul-Ankara) and the remaining traces of the interprovincial railroad lines. On the southern front, there lies the traditional residential area, the only hill of the lowland-city. Historically, the city was primarily built on the skirts of the first southern hill and, over time, expanded towards Porsuk River. Since the campus settlement utilized by the university students who created the cognitive maps resides in this historic area, the students often provided a place for this district in their cognitive maps. It is evident in the cognitive maps that the students often reached their destinations in the city by walking and using public transport, especially the tram.
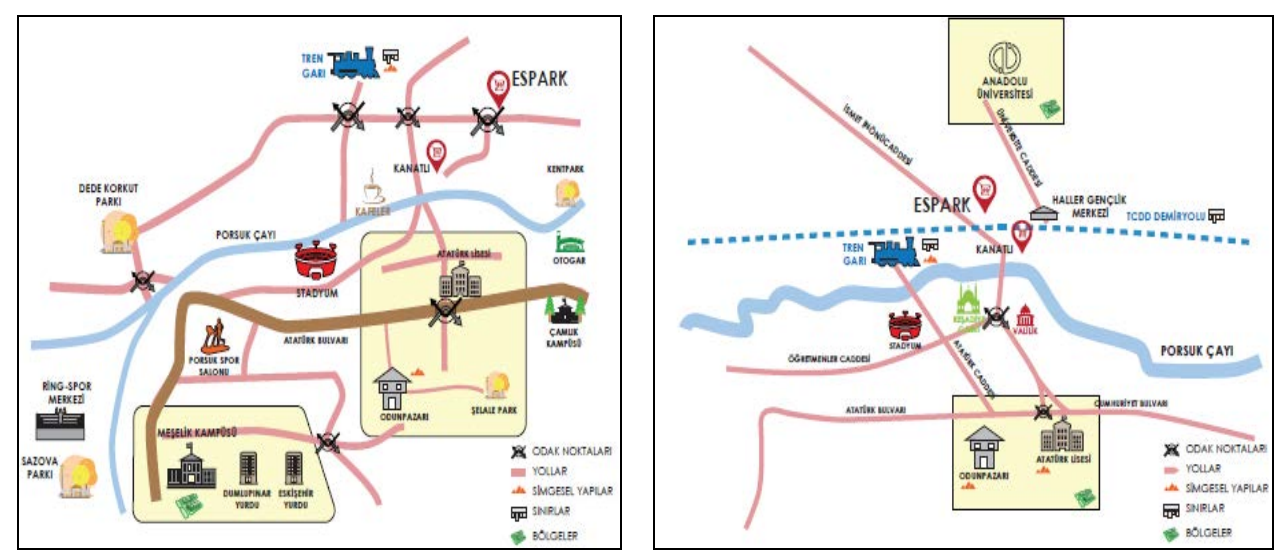

Figure 2: The cognitive maps converted into a language of graphical representation. 
Moreover, although university students commonly utilized bicycles in the city, this is not true for the architecture students, who study at the campus located in the historic settlement on the hilly outskirts, due to the challenging climb uphill.

\subsection{Discussion}

In a study entitled "Urban Identity in an Era of Cellphones", conducted by Barlas and Şentürk in 2011 [24], the contribution of wireless communication technologies, especially cellphones, to reading the urban identity was investigated. According to their research, the old gathering locations in the city that were utilized as landmarks disappeared, various meeting locations that are not easily recognized were formed, open spaces such as streets became meeting locations, due to the widespread utilization of wireless communication technologies [24]. Although the developing technology renders an easier legibility for the city, it is possible to assert that a legibility that is created through the totality of an individual's perceptions and experiences would be more permanent and personal.

\section{CONCLUSION}

Cities, which grow and change in time and accumulate the former assets in memory, are examples for the human creation. Several elements in the cities (structures, landscapes, squares, etc.) continue their persistence through witnessing different periods, starting from the moment they exist. Some of these elements owe their permanence to their existence in a unique context. The persistence of others, on the other hand, depend on their ability to serve different functions over time, by conveying past to the present. These persistent elements demonstrate what the city was previously. These elements constitute the urban artifacts, as of the conscious and memory they express and of being determinants in shaping the city. It is observed that the urban artifacts, namely the streets, parks, water items, sculptures, public buildings, etc., occupy a significant place in people's daily lives for activities such as walking, meeting, resting, entertainment, etc. [21].

The strongest sense of place experience is what Relph calls existential insideness - a situation of deep, unself-conscious immersion in place and the experience most people know when they are at home in their own community and region. The opposite of existential insideness is what he labels existential outsideness - a sense of strangeness and alienation, such as that often felt by newcomers to a place or by people who, having been away from their birth place, return to feel strangers because the place is no longer what it was when they knew it earlier [25].

\section{REFERENCES}

[1] Lang, J., Creating Architectural Theory: The Role of the Behavioural Sciences in Environmental Design, Van Nostard Reinhold Company: New York, p. 90, 1987.

[2] Schulz, N., Existence, Space and Architecture, Studio Vista: London, pp. 9-37, 1971.

[3] Downs, R.M. \& Ve Stea, D., Cognitive maps and spatial behavior: Process and products. Image and Environment, eds R.M. Downs \& D. Stea, Aldine: Chicago, IL, pp. 8-26, 1973.

[4] Baskaya, A., Yalin Bir "İsaret Dizgesi”, Gazi Univ. Muh. Mim. Fak. Der. Cilt 16, no. 2, pp. 63-75, 2001.

[5] Rapoport, A., Human Aspects of Urban Form: Towards a Man-Environment Approach to Urban Form and Design, Pergamon Press: UK, 1977.

[6] Lynch, K., The Image of the City, MIT Press, Cambridge, 1960. 
[7] Stea, D., Architecture in the head: Cognitive mapping. Designing for Human Behaviour: Architectural and Behavioural Sciences, eds J. Lang, C. Burnette, W. Moleski \& D. Vachon, Dowden Hutchinson \& Ross Inc.: Stroudsburg, PA, 1974.

[8] Stefanou, J., Environmental iconolgy. A Tool for Analysis for the Qualitative Improvement and Touristic Development of Places, Tourism and the Environment, eds H. Briassoulis \& J.V.D. Straaten, Kluwer Academic Publishers: London, pp. 35-41, 1992.

[9] Bayramoğlu, N., Kullanıcı Algısı Bağlamında Kentsel Kimlik: Barbaros Bulvarı Büyükdere Kentsel Aksı [Urban Identity in the Context of User's Perception: Barbaros Boulevard - Buyukdere Street Urban Axis], İTÜ Fen Bilimleri, Yüksek Lisans Tezi: İstanbul, 2010.

[10] Herzog, T.R. \& Leverich, O.L., Searching for legibility. Environment and Behavior, 35, p. 459, 2003.

[11] O'Neill, M.J., Evaluation of a conceptual model of architectural legibility. Environment and Behavior, 23(3), p. 259, 1991.

[12] Köseoğlu, E. \& Onder, D.E., Subjective and objective dimensions of spatial legibility. Procedia - Social and Behavioral Sciences, 2011.

[13] Banger, G., Once upon a time: Eskişehir and minorities, 2011. http://www.duygudu suncesi.net $/ \mathrm{p}=5259$

[14] Ertin, G., The evolution of habitation in Eskişehir, Anadolu University, Eskişehir, p. 23, 1994.

[15] Y1lmaz, T.E., The processes having a determining role in the development of Eskişehir and the settlements appeared within those processes, Master's Thesis, Eskişehir Osmangazi University, Institute of Science, 2009.

[16] Kılınç, K. \& Kaçar, D., In pursuit of a European city: Competing landscapes of Eskişehir's riverfront. Contemporary Urban Landscapes of the Middle East, ed. M. Gharipour, Routledge: New York, pp. 45-66, 2016.

[17] Ozturk, A.C. \& Kizildogan, E.T., Yaşlı Bireylerin Kentsel/Kamusal Mekanları Kullanım Analizi: Eskişehir Örneği [The analysis of the use of elderly individuals of urban/public spaces: the case of Eskişehir]. Yaşlı Sorunları Araştırma Dergisi (YSAD), Elderly Issues Research Journal (EIRJ), 10, 2016.

[18] Yerli, G., Sürdürülebilir Kent İçi Hareketlilik Planları (SUMP) Çalıştay Raporu, Yaşanabilir Şehirler Sempozyumu, İTÜ, 2015.

[19] http://www.eltis.org/discover/case-studies/pedestrian-friendly-city-centre-eskisehirturkey

[20] Golledge, G. \& Gärling, T.R., Cognitive maps and urban travel, 2002. https://escholarship.org/uc/item/5wb4524r

[21] Ozturk, A.C., Eskişehir'in Geçmişteki Ve Bugünkü Kent Belleğinin Zihin Haritaları Üzerinden Okuma Denemeleri [A reading attempt of the past and present urban memory of Eskişehir via cognitive mapping]. Special Issue on Memory and Urban Conservation II, Journal of Urban Studies, (20), 2016.

[22] Karataş, Z., Sosyal bilimlerde nitel araştirma yöntemleri. Manevi Temelli Sosyal Hizmet Araştırmaları Dergisi, 1(1), pp. 62-80, 2015.

[23] Corbin, J. \& Strauss, A., Grounded theory research: Procedures, canons, and evaluative criteria. Qualitative Sociology, 13(1), pp. 3-21, 1990.

[24] Barlas, A. \& Şentürk, M., Urban identity in the age of the mobile phone. METU JFA, 1(28:1), pp. 109-129, 2011.

[25] Seamon D. \& Sowers J., Place and Placelessness, Edward Relph, Human Geography, SAGE: London, pp. 43-51, 2008. 